\title{
FAVORABLE ECONOMIC IMPLICATIONS OF THE FAIR LABOR STANDARDS ACT
}

\author{
OTto NATHAN*
}

The most important favorable implication of the Fair Labor Standards Act is the federal statutory recognition of the fact that the living conditions of those in the lowest income group should not be determined solely by the anonymous forces of the market mechanism. The Fair Labor Standards Act is a denial of the thesis that an competitive market without any regulatory interference will result in the greatest good for the greatest number of people. It postulates the necessity of considering human labor no longer as a "commodity" which is subject only to the iron laws of the market mechanism.

The theory of the free market presupposes the existence of complete freedom of trade and of free competition. It further assumes the efficiency of the price mechanism which is supposed to be the supreme arbiter of such a system. If prices-commodity prices, wages, interest rates, and any other prices-are not interfered with, they will, it is assumed, operate as a regulator between supply and demand, production and consumption, savings and investments, etc. They will force production up if the demand for commodities is larger than the supply offered. They will lead to a curtailment of production, if consumption cannot keep pace with it. The rise and fall of prices will automatically indicate the maladjustments in the various markets and will make corrective reactions not merely possible, but actually inevitable. It has been assumed that no major "maladjustment," such as a depression, could exist for any length of time if the free market mechanism were allowed to operate fully and unrestrictedly.

In large parts of our complicated economic system this theory of the market mechanism is not applicable. Because of many monopolistic and semi-monopolistic institutions and controls, free competition has never existed in the past and does not exist at present. At no time were conditions in the market such that the mechanism was able to work efficiently and to operate as it was expected to do in pure theory. Corrective reactions and readjustments either did not develop as they were supposed to, or else occurred tardily, slowly and sporadically. Economic development, there-

* Ph.D., 1920, University of Wuerzburg, Germany. Associate Professor of Economics, New York University, since r936. Federal Statistical Office and Federal Department of Economics, Germany, 1920-1933; Lecturer, Hochschule fuer Politik, Berlin, Germany, 1928-1933; Visiting Lecturer, Princeton University, 1933-r935. Contributor to various periodicals on economics. 
fore, has been characterized by instability and insecurity, by breakdowns and depressions. But it is by no means certain whether greater stability would have prevailed, and would prevail now, if free competition had been more complete in the past and if it were more complete today. The cumulative processes ${ }^{1}$ that are so greatly responsible for the deepening and widening of economic disturbances, might be even more powerful under complete freedom of trade than under the existing system of interferences and restraint.

Strangely enough, there has been one market in this country, ever since the dawn of capitalist development, where free competition has existed to a much greater extent than elsewhere: the labor market. Wages and the working conditions have been mainly the result of free competition among the workers and of individual competitive bargaining by the workers with the employers. But since the employers rather frequently have enjoyed monopolistic or semi-monopolistic positions and protection, unlimited competition on the supply side in the labor market has added to the disadvantages of the working class in bargaining with the entrepreneur. The worker has been forced to sell his "commodity," human labor, in the same way as many other commodities are sold. However, to allow the price of human labor to be fixed by the anonymous and impersonal forces of an invisible market mechanism, means to disregard the decisive differences between all other commodities and the "commodity," human labor. Human labor is the most perishable commodity that exists; if it cannot be sold instantly, it will be lost forever. In addition, the demand for and supply of the "commodity" do not follow the laws governing supply and demand of all other commodities. A decline in its price does not lead to a curtailment of its production and, therefore, to an automatic readjustment of market conditions. On the contrary: a decline of wages is usually accompanied by an increase in the supply of human labor, by unemployment. The more wage rates decline, the greater is the pressure on wages because of the increasing supply of, and declining demand for, labor. And, finally, the "commodity," human labor, unlike any other commodity, is embodied in human beings, whose health and very existence depend on its sale.

For all these reasons, the workers as a whole are handicapped by extremely unfavorable conditions in bargaining about the price of their "commodity" with the employers in a competitive market, as Adam Smith pointed out in The Wealth of Nations. To assert that their wages tend towards what neo-classical theory has called their "marginal net product" is to ignore the realities of the labor market. The "marginal net product" of labor ${ }^{2}$ is a highly abstract and hypothetical, not to say artificial, concept of neo-classical economic theory. Its theoretical validity depends, in the opinion of its defenders, on a large number of assumptions, that do not correspond with the realities of modern economy. To mention only a few, which

\footnotetext{
${ }^{1}$ Concerning the nature of cumulative processes see von HaberLer, Prosperity and Depression (r937) $223 \mathrm{ff}$.

${ }^{2}$ Space does not permit dealing with the marginal productivity concept at greater length.
} 
are particularly important: free competition among the employers in their demand for labor often does not exist; mobility of capital and labor has declined very considerably; and rarely is work available for everybody who wants to work for a wage equal to what economists might consider to be the "marginal net product" of labor. The "marginal net product" defies any measurement and offers no criterion which could guide the employers, and, more important, the workers, in bargaining about wages and conditions of work. The conceptual approach of the marginal productivity theorists completely ignores the significance of the different economic positions of the two partners in the labor contract. And it disregards the fact that the "marginal net product," and consequently wages, often declines only because poor management or new developments at home or abroad have reduced the gross returns of the enterprise without, however, reducing the profits of the entrepreneur.

The passage of the Fair Labor Standards Act implies the acceptance of the thesis that actual experience has proved it impossible to apply the assumptions of a free market mechanism to the labor market in a modern economy. ${ }^{3}$ The most significant result of the Act, therefore, is the protection that it affords to the worker in bargaining with the employer. By curtailing free competition in the labor market to a small degree, the Act merely helps labor to catch up with similar developments in other markets that have occurred long before. By fixing maximum hours and minimum wages, the Act assures the worker a livelihood that, in numerous cases, he otherwise might be unable to secure, as a result of the intricacies of free competition on the supply side and because of his weak position in the labor market. The limitation of free competition on the supply side of the labor market makes it impossible for irresponsible employers, lacking in social consciousness, to take unfair advantage at the expense of the worker. ${ }^{4}$

While the protection of the "marginal" worker and of the worker below the "margin" is by far the most important aspect of the Act, it will also affect economic developments favorably in various other directions. Those enterprises whose productivity is low and which, therefore, can exist only under conditions of work exceedingly unfavorable to labor, will eventually be forced out. If certain enterprises in some industries are unable to make the changes prescribed by law and are unable to increase their efficiency, their production will be shifted to the more efficient enterprises. Such a development is very much to be desired from the point of view of the entire economy. In Great Britain, the Trade Boards which, for the last thirty years, have been responsible for the fixing of minimum wages, have been very successful in forcing industries to reorganize. Many businesses which could maintain themselves only by the payment of sweated wages, have been forced out of existence.

\footnotetext{
a The necessity for state-enforced regulation of conditions of work has been frequently stressed by many neo-classical economists. See, f. i., Taussig, Principles of Economics (3d ed. rg2I) 299 ff. and 318 ff.

'See Frankfurter, Dewson, and Commons, State Minimum Wage Laws in Practice (National Consumers League, x924) 5 I ff. which contains letters from employers and employers' associations, stating that minimum wage regulation "takes the question of wages very largely out of competition and saves them from the necessity of holding wages down to the level of their hardest and shrewdest competitor."
} 
But, on the whole, they have been replaced by more efficient units which have been able to support the higher rates. Wages have risen; employment has not diminished. ${ }^{5}$

The process of reorientation of material and human resources towards industries with a greater comparative advantage might be long-drawn-out and painful, but in the end it will result in greater efficiency and higher productivity. It is possible that the disappearance of individual businesses may result in transitory unemployment until workers can be absorbed by more productive industries or enterprises. ${ }^{6}$ This merely means that society, as a whole, has to assume responsibility for them through relief or unemployment insurance, ${ }^{7}$ instead of enjoying the fruit of their work at prices which do not guarantee them a decent livelihood. Both in Great Britain and in the United States, minimum wage legislation in the past has not led to permanent unemployment. Sooner or later the displaced workers will find employment in industries where their work will be more productive and efficient-a permanent gain for the whole economy. ${ }^{8}$

Since employers are compelled to comply with the minimum conditions set by law, they will attempt to increase managerial efficiency and to improve the entire organization of their business; they will introduce new machinery which guarantees a more economic use of existing resources. This is especially true in all cases in which some enterprises in a particular industry are more efficient than others and in which the less efficient units were able to compete successfully only by imposing bad working conditions on their workers. The minimum wage legislation in the State of California led to standardization, to more efficient management, and to the elimination of inefficient minor workers under 16 years of age in the canning industry. Efficiency was further increased in that industry by more adequate instruction of the employees, and unnecessarily long hours were limited by requiring increased rates for overtime. ${ }^{9}$ Similar effects have been experienced in England. According to the British Ministry of Labor, it is the general opinion that the imposition of Trade Board minimum rates encouraged employers to make various adjustments in the direction of greater efficiency within their works. In nearly all cases examined in a certain year wage increases had been accompanied by organizational economies; some employers actually praised the minimum wage legislation as an incentive to

\footnotetext{
${ }^{5}$ Hetherington, The Working of the British Trade Board System (1938) 38 INT. LAB. Rev. 478, 479.

${ }^{\circ}$ Fears were originally expressed that the Fair Labor Standards Act would lead to large-scale unemployment. The information so far available shows that these fears were not justified. See Andrews, "We Have Come a Long Way" (I939) 6 LaB. InforM. Bull. No. 4, pp. I ff.

${ }^{7}$ It should be pointed out that, in some cases, wages are so low, that the community has to pay relief even to the workers who are employed. See Pidgeon, Women IN the Economy of the United States (U. S. Dept, of Labor, r937) 7o.

8 "Although there have been individual instances of displacement (by state minimum-wage legislation for women and minors in the U. S.) the general trend in employment has shown an increase in both the number and the proportion of women, gainfully occupied." The Minimum Wage-AN INTERnational Survex, I. L. O. Studies ANd Reports, Series D, No. 22 (1939) 237. The experience in Great Britain, resulting from minimum wages for both men and women, has been even more conclusive. See Sells, BRItISH WAGE BoARDS (The Brookings Institution, I939) $294 \mathrm{ff}$., and Hetherington, loc. cit. stupra note 5.

${ }^{\circ}$ Frankfurter and Dewson, Brief in support of the California Minimum Wage Law, in Frankfurter, Dewson, AND Commons, op. cit. supra note 4 , at $5 \mathrm{r}$.
} 
industrial efficiency. ${ }^{10}$ Factory methods, including the introduction of machinery, especially in the clothing and laundry trades, have been stimulated by Trade Board rates, as a means of effecting operating economies to offset the extra burden imposed by an increase in wages. ${ }^{11}$ Similarly, a study made by the International Labor Office in I924 showed that in Sweden, Switzerland, Netherlands, Great Britain, France, the United States, etc. a reduction of hours stimulated improvements in equipment and in general organization of production and work. ${ }^{12}$

Higher wages and shorter hours will tend favorably to influence the health conditions of the worker and his family. Nutrition will improve; sickness will be less frequent. Improvements in the fitness of the worker and, therefore, in the efficiency of his work will be encouraged. The experience of the past few decades proves that shorter hours have led to improvements in both the quantity and the quality of production, and that these improvements are due, at least in part, to the greater efficiency of the workers. This increase in efficiency is, in turn, attributed to improved health, greater reserves of energy, a more favorable attitude toward the job, and more intelligent activity on the part of the worker. ${ }^{18}$ Similar favorable results have often accompanied increases in wages. Better wages have made "better fed, healthier, and better satisfied workers; and they tend to result both in a better quality of work and in greater unit output."14 The Industrial Welfare Commission of the State of Washington found that "the whole standard of efficiency and discipline has been raised."15

An increase in the productivity of human labor will, therefore, result from two different directions: firstly from the improvement of management and organization and from the concentration of production in the most efficient enterprises; and, secondly, from the increase in the efficiency, fitness, and health of the worker.

Finally, the Fair Labor Standards Act will have a favorable impact on the level of wages in the country as a whole and on the redistribution of national income in favor of the worker, at the expense of the employer. Wage totals will be increased ${ }^{10}$ in all cases in which existing low wages will be forced up by the Act and in which shorter hours will be introduced without a simultaneous decline in the weekly wages paid to individual workers. Further, the minimum established for wages and the maximum for hours cannot fail to have a permanent effect on wages and hours in

\footnotetext{
${ }^{10}$ I. L. O., op. cit. supra note 8, at 139. $\quad{ }^{11}$ SELLS, op. cit. supra note 8, 325-326.

${ }^{12}$ Milhaud, Results of the Adoption of the Eight-hour Day: The Eight-Hour Day and Technical Progress (1925) I2 INT. LAB. Rev. 820 ff.

${ }^{13}$ See Commons and Andrews, Principles of Labor Legistation (4th ed. 1936) 85 ff; Florence, Economics of Fatigue and UNREst, aNd THE EFficiency of LABOR IN INDUSTRY (1924) 19; Florence, The Forty-eight Hotr Week and Industrial Efficiency (1924) Io INT. LAB. Rev. 729 ff; Milhaud, Restilts of the Adoption of the Eight-hour Day; The Eight-hour Day and the Human Factor in Production (I926) I3 INT. LAB. REv. I75 ff.

14 See SELls, op. cit. supra note 8, at 325. The British Board of Trade declared that "there are indications that in many cases the efficiency of the worker has been increased." Commons AND ANDnEws, op. cit. supra note 13 , at 74 .

${ }^{15}$ First Biennial Report of the Industrial Welfare Commission, State of Washington (I915) 13.

${ }^{16}$ In very special cases, this might not be so for a transitory period of time.
} 
general. As experience here and abroad shows, wages will tend to be higher and hours shorter than they were before the new legislation. A publication of the United States Department of Labor states that "there is considerable testimony to the definite effects minimum-wage legislation in this country has had in raising women's wages. ${ }^{17}$

The trend towards higher wages and shorter hours in the economy will, no doubt, occur very slowly. Its speed and extent will depend partly on the general economic situation at the time the various stages of the Act go into force. Should large-scale unemployment prevail at the time of the introduction of higher minimum wages and shorter maximum hours, the effect on the rest of the economy will be much less significant than if such changes occur at times of a boom or, at least, of prosperous business conditions. To what extent the distribution of national income will change, will mainly depend on whether entrepreneurs will find it possible to shift the increase in cost, resulting from higher wages or shorter hours, to the consumer by increasing the price of their commodities. In businesses of a monopolistic nature, that may be possible, at least to a certain extent. Similarly, prices of commodities which enjoy a very inelastic demand may be raised on account of higher wages and shorter hours. In both cases, such price increases will be possible only if the production of cheaper substitutes is unlikely and when competition from abroad does not exist or is made ineffective by tariffs. On the other hand, part of the decline in profits will be counterbalanced by the increase in efficiency and productivity which will result from the Act. Although much will depend on conditions in individual industries and enterprises, it can be assumed that some, very modest, decline in profits may occur, in spite of the shift of higher costs to prices, and in spite of the favorable effects on labor productivity. To a certain, perhaps rather small, extent a redistribution of national income will occur, therefore. It will become more considerable when the final stages set down in the Act are attained. The economic effects of such a change are very desirable. Any development that tends to increase labor's share in the national product will help to reduce the instability from which the economy has suffered in the past. It will help to employ more permanently the human and natural resources which the country possesses. And, by so doing, it will help, from a different direction, to reduce the human suffering, to the elimination of which the Fair Labor Standards Act is designed to contribute.

\footnotetext{
${ }^{17}$ See Pidgeon, op. cit. supra note 7, at IoI ff; Comasons AND ANDREws, op. cit. supra note 13 at $68 \mathrm{ff}$; I. L. O., op. cit. supra note 8 at 233 ff; U. S. Department of Labor, Women's Bureau, The Development of Minimum-Wage Laws iN THE Unted States, I912-1927, Bulletin No. 6i (r928) 370 et passim; Effect of Minimum Wage in Dry-Cleaning and Laundry Industries (1939) 18 Mo. Lns. REv. 370 ff. For similar experiences in Great Britain see I. L. O., op. cit. supra note 8, at 134 ff, and SELLS, op. cit. supra note 8 , at 270 .
} 